\title{
DEVELOPMENT MORPHOLOGY OF Undaria pinnatifida SPOROPHYTES (PHAEOPHYCEAE, ALARIACEAE) IN CALETA CORDOVA (CHUBUT, ARGENTINA)
}

\author{
María Victoria Alvarez ${ }^{1,2}$ and Alicia Boraso ${ }^{2}$ \\ ${ }^{1}$ Departamento de Biología, Facultad de Ciencias Naturales y Ciencias de la Salud, \\ Universidad Nacional de la Patagonia San Juan Bosco (UNPSJB), \\ Ruta Nacional No $1 \mathrm{~km} 4 \mathrm{~s} / \mathrm{n}$, Comodoro Rivadavia, Argentina \\ e-mail: marivikalvarez@gmail.com \\ ${ }^{2}$ Consejo Nacional de Investigaciones Científicas y Técnicas (CONICET), \\ Instituto de Desarrollo Costero "Dr. H. C. Héctor E. Zaixso", Centro de Investigación y \\ Transferencia "Golfo San Jorge", Universidad Nacional de la Patagonia San Juan Bosco (UNPSJB), \\ Ruta Nacional No 1 km 4 s/n, Comodoro Rivadavia, Argentina
}

\begin{abstract}
Undaria pinnatifida is an invasive brown algae that has been found on the Argentine coast since 1992. This work aims to follow the ontogeny of sporophytes, from egg fecundation to thallus senility, and thereby contribute to information on the development of the species in San Jorge Gulf. Sporophytes obtained in the laboratory were used to study the first stages of development, while samples collected from field population were used to describe advanced stages. Morphological observations were carried out on fronds, stipes, midrib, sporophylls and holdfasts of thalli at different developmental stages, and they was interpreted related to its functionality. Sporophytes described as typical and distant forms were found, and their location in the coastal zone was determined. Primary growth of sporophyte begins in the intercalar meristoderm located between the frond and the stipe. The upper portion of the intercalar meristem produces a row of small pinnules, and its lower portion is the origin of the lateral stipe ribbons. The thallus area and growth in thickness occur through a meristoderm in the frond surface. Characteristic morphological structures such as gland cells, filaments and trumpet cells, and cryptostomata were observed. Some of the gland cells lead to the formation of hair-filled cryptostomata. This work contributed to increase the knowledge of anatomical characteristics of the thallus at different moments of development of this invasive species.
\end{abstract}

Key words: Morphology, Undaria pinnatifida, invasive species, San Jorge Gulf, sporophytes, meristoderm.

\section{INTRODUCTION}

Undaria pinnatifida (Harvey) Suringar, 1873 is an invasive brown algae, native from Japan, southern China and Korea (Saito 1975). This species was introduced in several coastal areas and has become established in the Mediterranean Sea, European Atlantic, New Zealand, Australia, Tas- mania and Argentina. The arrival of Undaria to the Mediterranean coast was reported by Perez et al. (1981), and it is believed that it was introduced along with the Japanese oyster Cassostrea gigas for cultivation (Boudouresque et al. 1985; Floc'h et al. 1991). Later, Undaria was recorded along the coast of Brittany and was subsequently registered on the Atlantic coasts of England and Spain (Perez et al. 1984; Santiago Caamaño et al. 1990; Fletcher and Manfredi 1995). Numerous works on 
the introduction and dispersal of Undaria on the European coasts (Hay 1990; Rismondo et al. 1993; Salinas et al. 1996; Cecere et al. 2000; Peteiro 2008; Minchin and Nunn 2014; Minchin et al. 2017, among many others), the Northeast Pacific (Silva et al. 2002; Aguilar-Rosas et al. 2004; Thornber et al. 2004; Dietrich and Lonhart 2010) and the Southern hemisphere (Hay and Luckens 1987; Stapleton 1988; Sanderson 1990; Campbell and Burridge 1998) can be mentioned.

In particular, on the Argentine coast (Figure 1) it was first detected in Nuevo Gulf in 1992 (Piriz and Casas 1994; Casas and Piriz 1996). By 1997, the species expanded $4.6 \mathrm{~km}$ north and $6.1 \mathrm{~km}$ south, while in 1999 it was found $12 \mathrm{~km}$ north and $22 \mathrm{~km}$ south (Piriz and Casas 2001; Casas et al. 2008). At the end of 2000, Undaria was registered on the coast of Camarones Bay (approximately $300 \mathrm{~km}$ south of Nuevo Gulf). In mid2005, Undaria was observed for the first time on the shores of Puerto Deseado estuary, $600 \mathrm{~km}$ south of the first point of entry (Martin and Cuevas 2006), and since then no records of the species further south have been made. During the first years of the invasion, the species only spreaded to the south, suggesting that Valdés Peninsula represented a natural barrier to its dispersal; notwithstanding it was observed in San José Gulf in 2008. Consequently, it is estimated that its arrival to San Matías Gulf was in 2010 (Pereyra et al. 2014), while its presence on the coasts of Buenos Aires Province (Mar del Plata city) was documented in 2011 (Meretta et al. 2012), thus leading to the speculation that it could reach Uruguay and even southern Brazil (Dellatorre et al. 2014).

The introduction of $U$. pinnatifida can occur accidentally, as in the case of the Mediterranean Sea (Perez et al. 1984), the Venice Lagoon (Curiel et al. 1994), New Zealand (Hay and Luckens

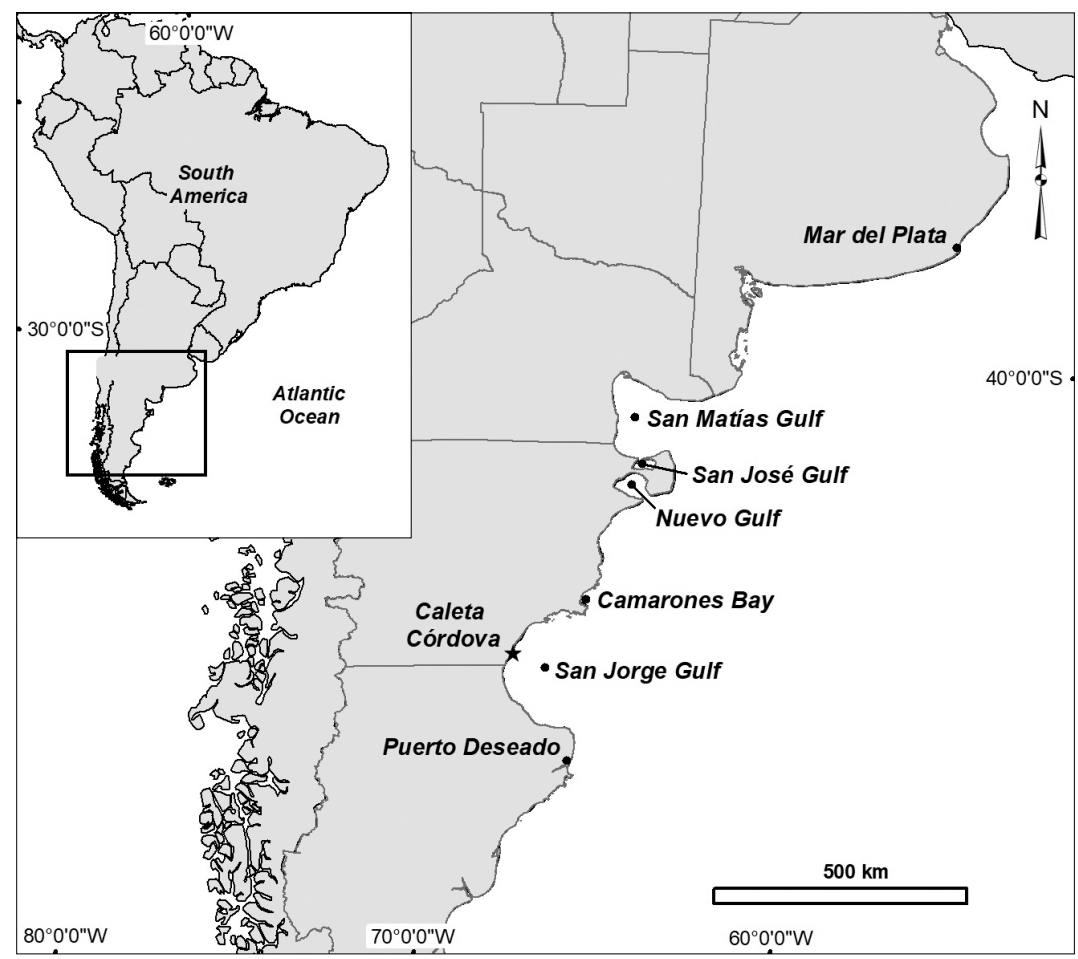

Figure 1. Study area indicating locations in the Patagonian coast of Argentina. 
1987) and Argentina (Piriz and Casas 1994), or intentionally for aquaculture. This species was first introduced for culture experiments on the coast of Brittany (Perez et al. 1984; Castric-Fey et al. 1993) and was subsequently introduced in Spain for the same purpose (Perez-Cirera 1997; Peteiro 2001 in García and Peteiro 2015). The most important vector of accidental dispersion is via maritime traffic through fouling on ship hulls, such as gametophytes or small sporophytes, or through spores in ballast water discharge (Williams and Smith 2007). Dispersion through fouling is mentioned by Fletcher and Manfredi (1995) for Southern England, Curiel et al. (2002) for the Island of Venice, and Minchin and Nunn (2014) for Northern Europe, among others. The introduction of Undaria through ballast water discharge has been reported for New Zealand, Tasmania and Argentina (Hay and Luckens 1987; Sanderson 1990; Piriz and Casas 1994).

Distribution and reproductive stages of Undaria in Argentine coast were analyzed by Casas and Piriz (1996) after its entry into Nuevo Gulf. Subsequently, same authors studied the impact of the species on the environment and how it dispersed (Casas and Piriz, 2001). In the north of Argentine Patagonia, Pereyra et al. (2015) analyzed the expansion of the species in San Antonio Bay.

Macroalgae are characterized by their largesized thalli, made up of a pinnate frond with a midrib, a stipe that separates the holdfast from the frond and in which the sporophylls develop upon reaching reproductive maturity, and a holdfast that adheres to the hard substrate (Guiry and Guiry 2014). This basic morphology presents an appreciable degree of variability (Yendo 1911; Okamura 1915; Castric-Fey et al. 1999; Cecere et al. 2000; Uwai et al. 2006) which has been thought to have genetic or plasticity components in the face of spatial or seasonal environmental variability. According to different authors (Stuart et al. 1999; Shibneva and Skriptsova 2012), most recognized forms of $U$. pinnatifida sporophytes are: a) Distant form, which corresponds to an elongated stipe, as long as the lamina, with large sporophylls limited to the basal area of the stipe and without proliferations; b) Typical form, with short stipe thalli and comparatively shallow sinuses between adjacent pines, far from the midrib. Upper parts of the sporophyllic zone are formed of large sporophylls (folds) confluent with the base of the frond; and c) Narutensis form (Yendo 1911) (= typical form, Okamura 1915), with very short stipes, slightly folded sporophyll zone, and ligulated proliferations of the sporophyll margins.

This study analyzes the ontogeny of the sporophyte, and aims to describe the developmental stages of $U$. pinnatifida, from egg fertilization to senility of the thallus. It represents a contribution to the knowledge of anatomical characteristics of the thallus at different moments of development of this invasive species, which have not yet been described for Caleta Cordova population (San Jorge Gulf).

\section{MATERIAL AND METHODS}

Study area is located in the central zone of San Jorge gulf(Figure 1), where U. pinnatifida is present. The coast of Caleta Cordova ( $45^{\circ} 44^{\prime} 22^{\prime \prime} \mathrm{S}$, $67^{\circ} 22^{\prime} 26.9^{\prime \prime} \mathrm{W}$ ) is made up of sedimentary rock with tidal pools and channels. Tides are characterized as semi-diurnal with average amplitude of $6 \mathrm{~m}$ (Zaixso et al. 2009). Middle and upper mesolithic horizon are covered with mussel Perumytilus purpuratus, while in the lower infralittoral zone Corallina officinalis can be found together with banks of Aulacomya atra and mussel Mytilus platensis (Gil and Zaixso 2008).

Morphological and anatomical observations of first stages of thallus development were studied in sporophytes obtained from cultures of gametophyte in the laboratory. More advanced stages were studied in sporophytes collected from field population. 
Thalli at different developmental stages were collected randomly each month from lower intertidal and upper subtidal zones of the rocky shore of Caleta Cordova during extraordinarily low tides or through scuba diving when necessary. Sporophytes were collected from April 2017 to November 2017 because of during December to March there are very few sporophytes on the ground, and most of them are senile with damaged structures. A total of 80 observations of Undaria thalli were made.

Gametophyte cultures were obtained monthly from spores released by fertile sporophytes. Ten cultures were started each month. Sporophyll materials located on slides were cultured inside glass containers filled with $150 \mathrm{ml}$ of enriched seawater renewed weekly. Gametophyte cultures were maintained in filtered seawater enriched with $1 \mathrm{ml}$ of stock solution $(3 \mathrm{~g}$ nitrates, $0.3 \mathrm{~g}$ phosphates, $0.7 \mathrm{~g}$ iron chloride, and $2 \mathrm{~g}$ EDTA per liter of seawater). Cultures were maintained between $10-14{ }^{\circ} \mathrm{C}$ (taking into account temperatures in natural conditions during harvest months) and irradiation of $40-80 \mu \mathrm{M} \mathrm{m}^{2} \mathrm{~s}^{-1}$ from a 40 -Watt fluorescent lamp (Pang and $\mathrm{Wu}$ 1996) under a 12:12 light: dark cycle. Development of sporophytes in these cultures continued until the frond reached about $3 \mathrm{~mm}$ in length.

In order to understand development stages at tissue level, sections ranging from $2 \mathrm{~cm}$ long to fully developed sporophytes were taken, covering the meristematic and mature areas of the frond, midrib, sporophyll, stipe and holdfast of each specimen. Microscopic observations and photographic records of these events were taken. Whole-mount slides, cross sections and longitudinal sections were made by hand with a stainless-steel razor blade. Photographs of unstained sections were taken with a Samsung digital camera and a Zeiss Standard 25 microscope. A sample of specimens was deposited in the Herbario Regional de la Patagonia (HRP) at the Universidad Nacional de la Patagonia San Juan Bosco, Comodoro Rivadavia (HRP 7480 to HRP 7502).
The development of the sporophyte was divided into stages according to an increasing order of structural complexity with respect to the number of cells (in the embryonic stages), tissue differentiation, presence of structures (such as glandular cells, cryptostomata and trumpet cells), length of the frond, presence of pinnae, and the reproductive state of the thalli. The development of the sporophytes was divided into the following stages:

- Embryonic postzygotic thalli (Figure 2 A).

- Embryonic laminar thalli, initially monolayered, up to 2-3 mm long (Figure $2 \mathrm{~B}$ ).

- Pre-sporophyllic juvenile thalli, before pinnae differentiation, less than $10 \mathrm{~cm}$ long (Figure $2 \mathrm{D}$ ).

- Pre-sporophyllic juvenile thalli, with differentiated pinnae, up to $30 \mathrm{~cm}$ long (Figure $2 \mathrm{E}$ ).

- Thalli, longer than $30 \mathrm{~cm}$, vegetative or reproductive, with an active growth zone between the frond and stipe (Figure 2 G, 2 I and $2 \mathrm{~J}$ ).

- Senile thalli of variable size with zones between frond and stipe completely filled with well-developed sporophyll, and immature juvenile thalli with blades and stipes damaged by environmental conditions (Figure $2 \mathrm{~K}$ ).

\section{RESULTS}

\section{Embryonic thalli}

Two successive embryonic stages were identified. The first one was the postzygotic embryonic thalli, which was monoseriate filament of 2-20 cells long. This stage began with the longitudinal division of the filament apical cell and the development of growth zones along the edge of the tiny frond (Figure $2 \mathrm{~A}$ ). The second stage was the embryonic laminar thalli with a length of $2-3 \mathrm{~mm}$ (Figure 2 B).

Germ tube (Figure $3 \mathrm{~A}$ ) and first gametophyte cells were produced during the first two weeks after liberation of viable spores. Female gameto- 

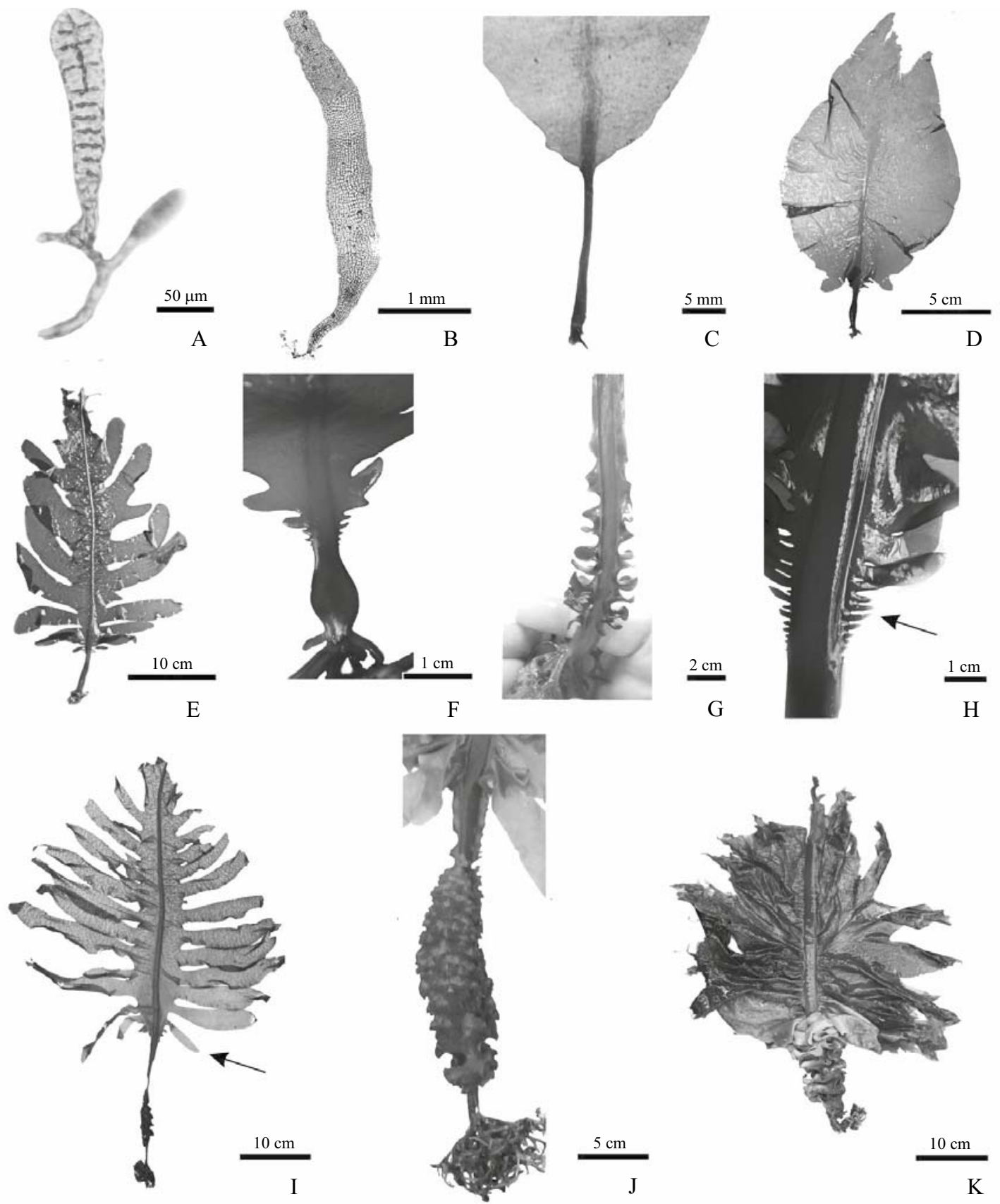

Figure 2. General external development. A) Embryonic post-zygotic thallus. B) Embryonic laminar thallus. C) Stipe before the formation of lateral wings. D) Pre-sporophyllic thallus with entire frond. E) Pre-sporophyllic thallus with pinnae. F) Initial stage of sporophyllic thallus with active growing zone between frond and stipe, and beginning of lateral wings. G) Stipe with folded sporophyll. H) Pinnulae growing into pinnae at the frond base. I) Sporophyll with frills restricted to the basal portion. This sporophyte corresponds to the distant form. J) Sporophyll in a more mature stage. K) Thallus with sporangial sori also developing on the basal portion of the frond without active growing zone remaining between the frond and the stipe. Sporophyte corresponds to the typical form. 

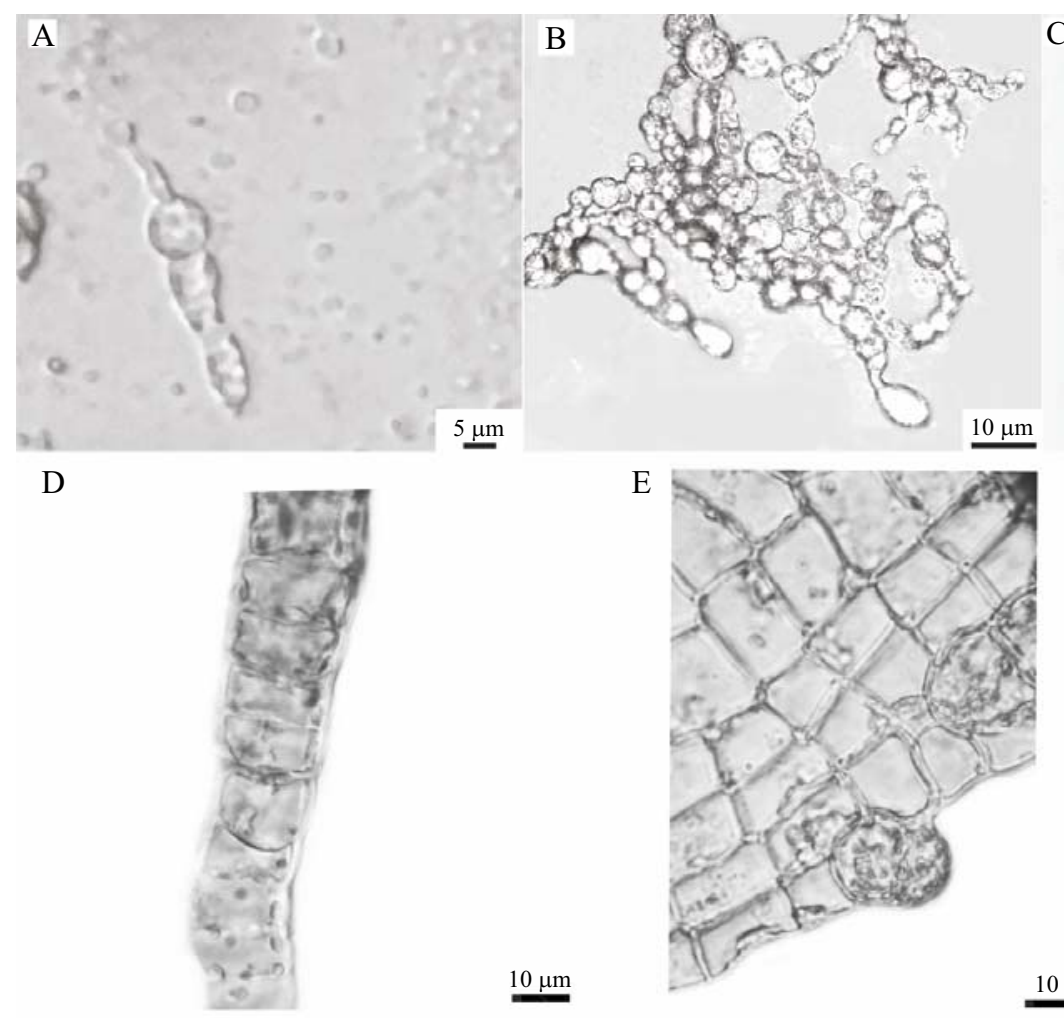

G

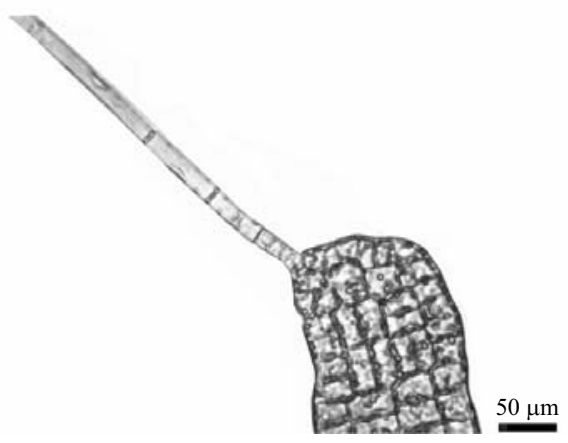

E

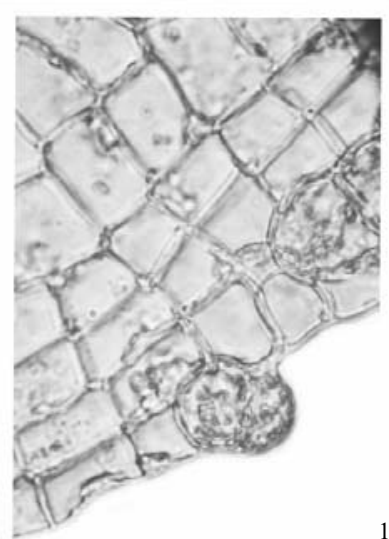

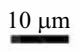

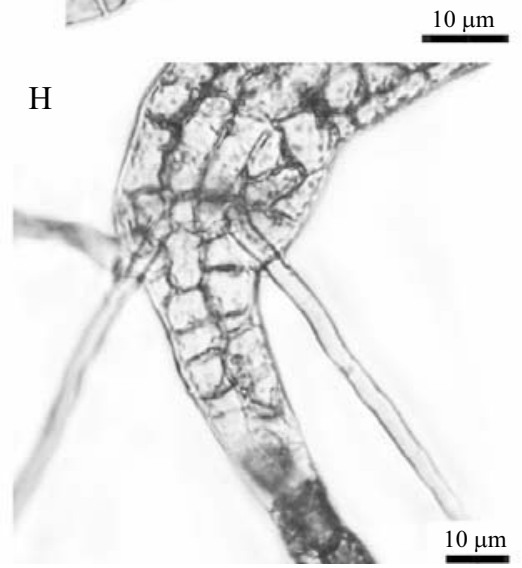

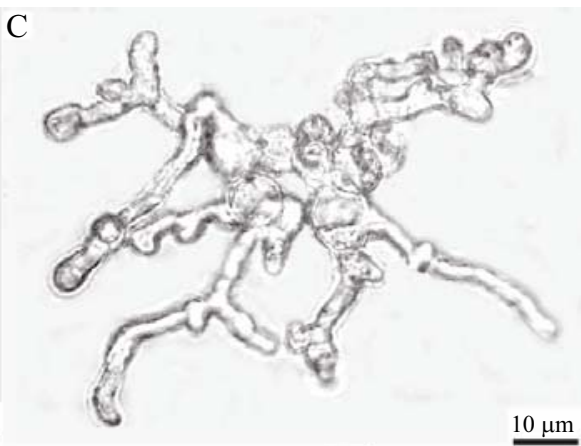

$\mathrm{F}$

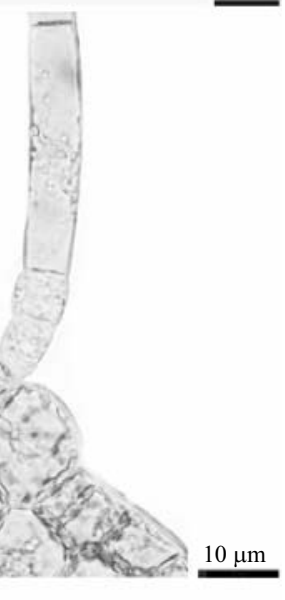

I

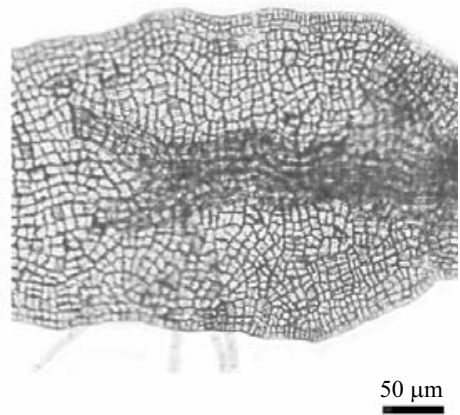

Figure 3. Embryonic thalli. A) Germ tube. B) Female gametophytes. C) Male gametophytes. D) Transversal section of singlelayered thallus. E) Hair primordium at the thallus margin. F) Phaeophycean hair. G) Subapical hair. H) Uniseriate rhizoids. I) ' $\mathrm{Y}$ '-shaped thickened central ribbon at the base of the embryonic frond.

phytes produced lateral rows of short filaments (Figure 3 B) with apical oogonia. After this, in the same conditions, mature male gametophytes (Figure $3 \mathrm{C}$ ) formed spermatangium which released one or more biflagellate anterozoids, that fertilized the oogonium.
Embryonic laminar thalli were initially monolayered (Figure 3 D). Solitary phaeophycean hairs with a basal meristem were seen on the surface or margins of small embryonic fronds less than $1 \mathrm{~mm}$ long (Figure $3 \mathrm{E}, 3 \mathrm{~F}$ and $3 \mathrm{G}$ ). These hairs were deciduous and left scars at their inser- 
tion points. The presence of these hairs could indicate a nutrient deficit in the culture medium used.

When the frond was about $2 \mathrm{~mm}$ long, its lowermost cells elongated and formed the beginning of the cylinder stipe, which adhered to the substrate through a few uniseriate lateral rhizoidal filaments (Figure $3 \mathrm{H}$ ). Thalli with this characteristic were collected from intertidal tide pools during autumn. At this stage, the frond was still monolayered and had a margin of small quadrangular cells (Figure $3 \mathrm{G}$ ); a region of smaller, apparently meristematic cells between the flattened frond and the cylindrical basal zone was observed. At the basal zone of the most advanced laminar embryonic thallus, a central darker ribbon similar to letter ' $y$ ' was frequently observed (Figure 3 I).

\section{Pre-sporophyllic juvenile thalli}

It was established that the embryonic stage was over and the pre-sporophyllic juvenile stage had started when the layer of meristoderm could be distinguished. Frond midrib began as a central ribbon of cells when the multilayered frond was only a few millimeters long. Meristodermic zone between the frond and the stipe could already be observed when the thallus was a few centimeters long. In this growing zone, short pinnulae were formed along the lower margins of the midrib (Figure $2 \mathrm{H}$ ). Later, pinnulae flattened and formed the lateral frond pinnae (Figure 2 I).

The apex of young pinnae had only one meristoderm layer (Figure $4 \mathrm{~A}$ ); however, a few layers of undifferentiated cells were produced inwardly close to the apex (Figure 4 B), and long medullary cells and a thin cortex of pigmented cells with some young gland cells were also observed. At the center of the fronds, and also along the sinuses of the growing pinnae, subepidermic cells produced some additional filaments which grew inwards and reached the cortex on the other side (Figure $4 \mathrm{C}$ ).
In young areas of the frond, the meristoderm with hyaline gland cells, the cortical tissue and the medulla (Figure $4 \mathrm{D}$ ) with young trumpet cells in formation could be observed (Figure $4 \mathrm{E}$ ). A few intermediate layers of somewhat elongated, less pigmented cells were observed between the outer pigmented cortex and the medulla. Young medulla consisted of trumpet cells that could be differentiated very early on (Figure $4 \mathrm{~F}$ ), and anticlinal filaments with diameters averaging $10 \mu \mathrm{m}$, forming a net, which could be either dense (Figure $4 \mathrm{G}$ ) or lax (Figure $4 \mathrm{H}$ ).

The external aspect of the surface differed depending on the age of the epidermal tissue, the distance to the growing margin and the presence of gland cells and hair-filled cryptostomata. In the younger zones, each meristodermic cell contained several parietal chloroplasts (Figure 4 I), and as the thallus became older the chloroplasts filled the cell volume (Figure $4 \mathrm{~J}$ ).

\section{Gland cell and cryptostomata formation}

Gland cells differentiated from meristoderm cells at the frond margins. Gland cells were denser (ca. 300 cells $\left.\mathrm{mm}^{-2}\right)$ in young thalli $(<5 \mathrm{~cm}$ long) (Figure $5 \mathrm{~A}$ and $5 \mathrm{~B}$ ) and in the apical portions of pinnae in more developed thalli. As the frond grew, gland cells became sparser and were found further from the frond margin. In older thalli, some gland cells could be found in the middle of the frond and the midrib, but never as dense as in young growing zones. Most of gland cells increased in volume and their content became hyaline (Figure $5 \mathrm{~B}$ ). They were usually very conspicuous because of their larger volume and the purple/burgundy to yellow color (Figure $5 \mathrm{C}$ ).

Enlarged cells at the surface were displaced below the meristoderm and became transition cells (TC) (Figure $5 \mathrm{D}$ ), which in turn produced the hair-filled cryptostomata. A pore opened in the meristoderm immediately over TC (Figure 5 E). TC developed several outgrowths towards the inside of the thallus (Figure $5 \mathrm{~F}$ ) and divided into small, lenticular cells with thickened edges 

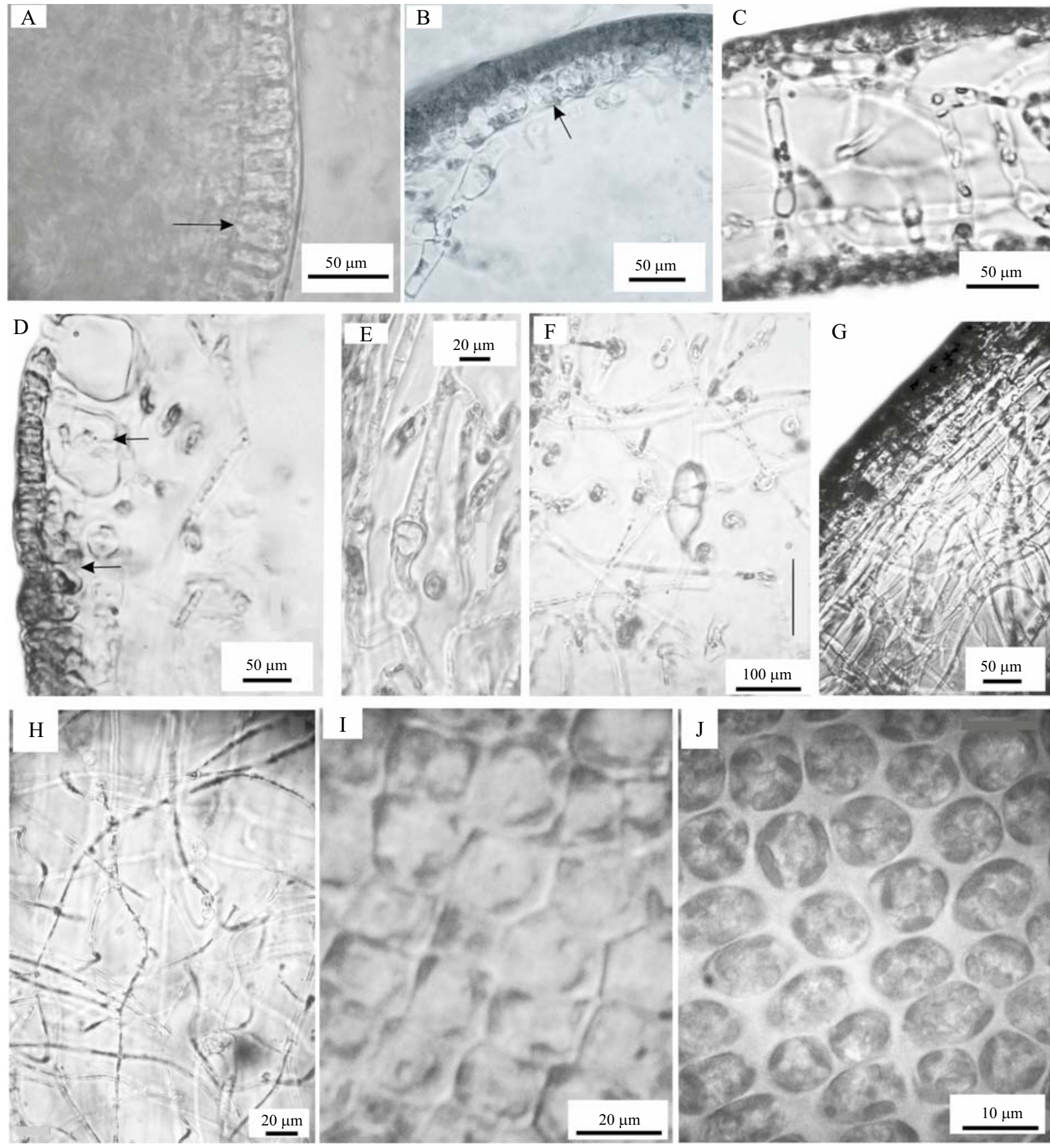

Figure 4. Frond structure. Longitudinal sections at the margin of a very young, monolayered thallus. A) Small meristoderm cells at the lobe apex. B) Single-layered cortex near to the apex. C) Cross section of a young portion of the frond with transverse medullary filaments. D) Cross section showing continuity between cortex and medulla. E) Formation of trumpet cells in the young medulla. F) Trumpet cells in older medulla. G) Cross sections in fully developed frond, compact medulla. H) Lax medulla. I) Surface view of meristoderm cells with chloroplasts. J) Surface view of meristoderm cell with chloroplasts at an older zone. 

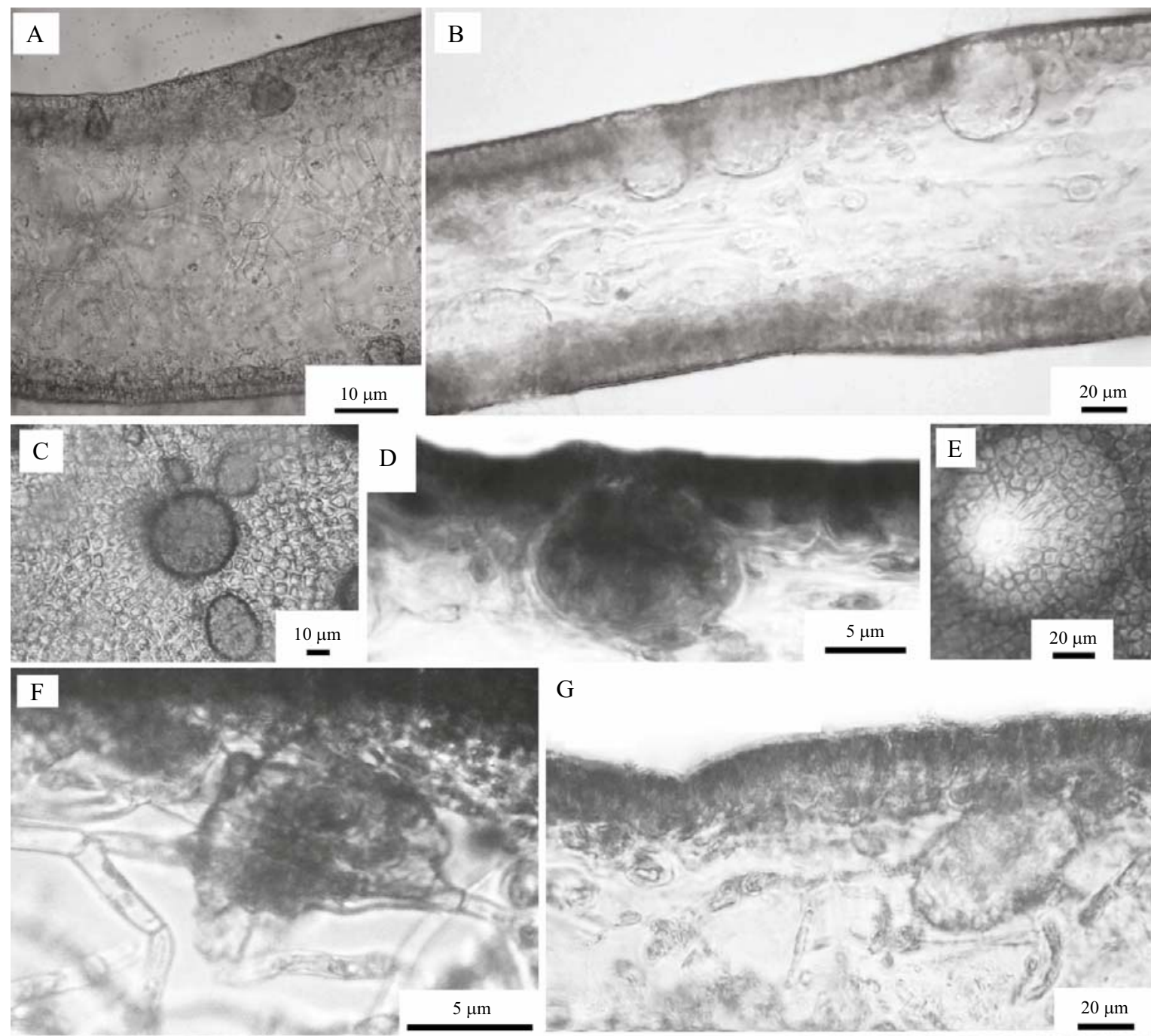

G
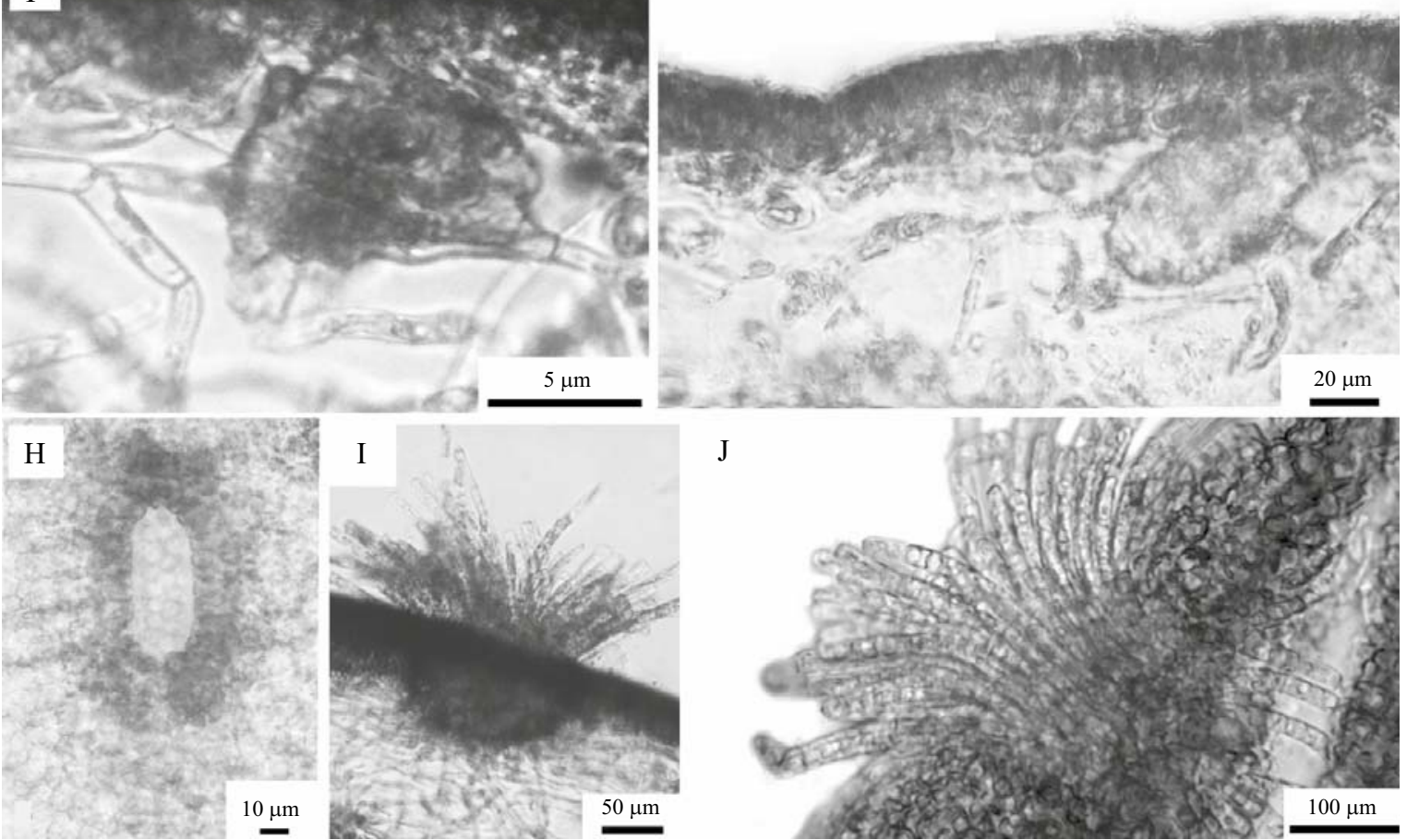

Figure 5. Gland cells and cryptostomata. A) Dark gland cells (GC) in young thalli. B) Hyaline GC in a young frond. C) GC superficial view. D) Transition cell (TC). E) Pore. F) Filaments growing inwards. G) Lenticular cells cross section of TC outer surface. H-J) Formation of cryptostomata. 
towards the outer surface (Figure $5 \mathrm{G}$ ). The lenticular cells became flat, polygonal with hexagonal outlines (Figure $5 \mathrm{H}$ ), which then divided transversely producing the hair primordia at the center of their outer surface. After some elongation, hairs appeared as a tuft through the pore in the meristoderm (Figure $5 \mathrm{I}$ and $5 \mathrm{~J}$ ). Hairs were firmly anchored into the thallus through the basal filamentous tissue of the crypt. They continued developing until reached several millimeters long and were observed as hyaline spots on the adult thalli at the naked eye.

\section{Midrib and stipe}

Sections of the midrib and stipe had a similar structure. Globose cells in the cortex were observed in the cross section of the midrib (Figure $6 \mathrm{~A})$ with the notable presence of a net-like structure of trumpet filaments in the medullary zone (Figure $6 \mathrm{~B}$ ). In the longitudinal section these cells elongated longitudinally (Figure $6 \mathrm{C}$ ). Cross section of the very young stipe had an external layer of strongly pigmented cells, a cortical zone formed of about ten rows of small cells (Figure 6 D) and a filamentous medulla (Figure $6 \mathrm{E}$ ). At the end of the pre-sporophyllic stage, the stipe was already compact and cortex cells became transversally globose and somewhat elongated longitudinally (Figure $6 \mathrm{~F}$ and $6 \mathrm{G}$ ). The medulla was limited to a thin, flat cell layer located in the middle of the frond. In this study, thalli up to $30 \mathrm{~cm}$ long remained at the pre-sporophyllic stage. At the end of this stage, two lateral wings were formed along the young stipe (Figure $2 \mathrm{~F}$ ).

\section{Sporophyllic thalli}

Thalli over $30 \mathrm{~cm}$ long showed some signs of sporophyll development. This development began at an early stage or just when pinnae could be distinguished on the frond. The lateral ribbon of the stipe generated sporophylls (Figure $2 \mathrm{~F}$ and $2 \mathrm{G})$. The surface of the lateral fringes along the stipe grew faster than the stipe in length, and this difference in growth led to the formation of the adult sporophyll frills. At first, the younger portion of the sporophyll adjacent to the primary meristematic zone was unfolded (Figure $2 \mathrm{G}$ ); as it matured (Figure $2 \mathrm{I}, 2 \mathrm{~J}$ and $2 \mathrm{~K}$ ) frills were seen along most of the stipe, and the entire length of the stipe was covered with frills when sporophyll development was completed. By this stage, no meristematic zones were left (Figure $2 \mathrm{~K}$ ).

Specimens with characteristics of Figure 2 I were collected between August and September in the upper subtidal, and these thalli belonged to the distant form. Thalli with characteristics of Figure $2 \mathrm{~J}$ were found in tidal pools of the lower intertidal and upper subtidal during spring months. These thalli belonged to the typical form.

Meristoderm, cortical and medullary layers were observed in the transverse section of sporophylls. The most distinctive feature was the presence of sori with unilocular sporangia and paraphyses on both sporophyll surfaces (Figure $6 \mathrm{H}, 6$ I, $6 \mathrm{~J}$ and $6 \mathrm{~K}$ ). Parparaphyses capped by mucilaginous masses protected the sporangia until the spores were released (Figure $6 \mathrm{~J}$ and $6 \mathrm{~K}$ ).

\section{Senescent thalli}

While sporophytes grew, distal zones of the fronds became damaged, and fronds became shorter and wider. In senescent thalli, which had attained full sporophyll development, reproductive sori also developed on the lowest pinnae of the frond (Figure $6 \mathrm{~L}$ ). At the end of the growth cycle, thalli which have lost the entire frond but still adhered by the holdfast presented remains of the sporophyll. These thalli were observed more frequently at intertidal tide pools or detached from the substrate during the summer.

\section{Adhesion of the adult thalli}

The holdfast was formed by dichotomic ramifications or haptera (Figure $7 \mathrm{~A}, 7 \mathrm{~B}, 7 \mathrm{C}$ and 7 D). Holdfasts adapted anatomically according to 

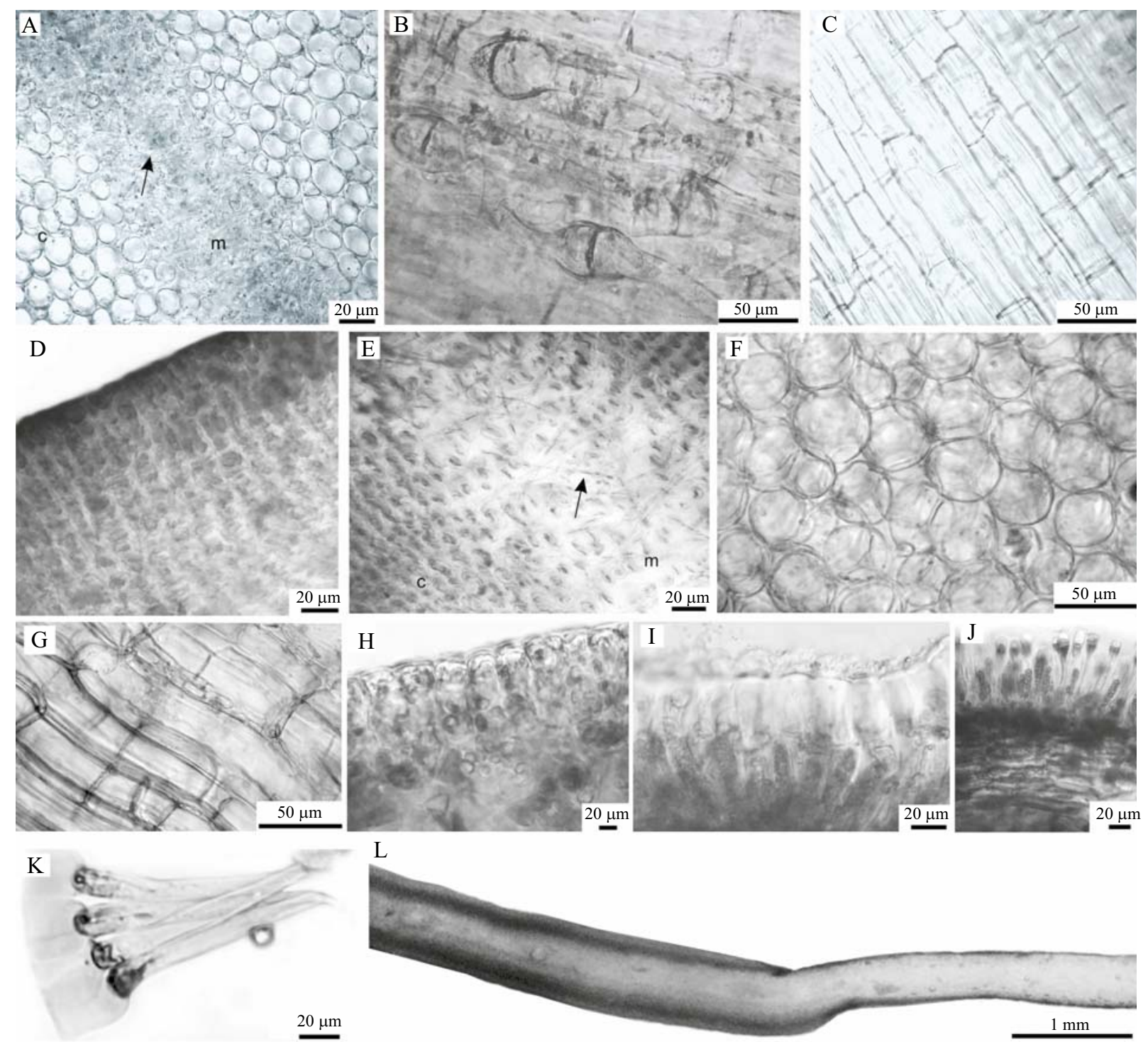

$\mathrm{L}$

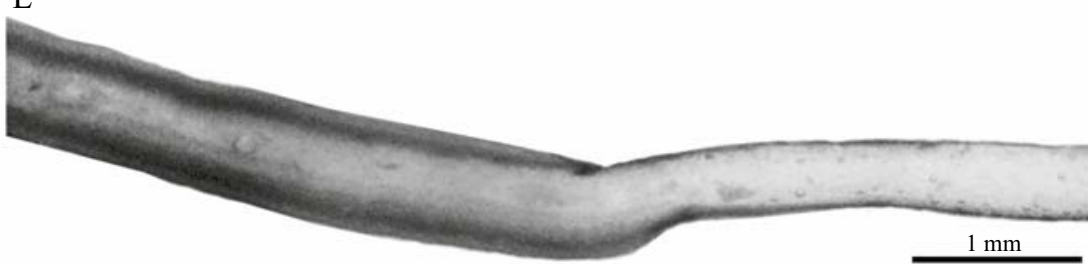

Figure 6. Midrib, stipe and sporophyle. Midrib: cross section (A), detail of medullary filaments (B), longitudinal section of midrib (C). Cross section of a young thallus stipe: cortex (D), flattened medulla (E), cross section with cortex in more developed thallus (F), idem in longitudinal section (G). Successive stages of development of sori: initial stages (H), later stage with gelatinous surface (I), detail of paraphyses with gelatinous distal walls (J), later stage with mature sporangia $(\mathrm{K})$, cross section at the lower portion of the frond in a senescent thallus, partially covered with sori (L). c: cortex. m: medulla.

the substrate. On hard substrates such as rock or encrusting coralline algae, the holdfast of the adult thallus consisted of a few sturdy branches (Figure $7 \mathrm{C}$ ). In contrast, haptera were crowded and medium sized on flat fronds, and when they were attached to branches of Corallinaceae, such as Corallina sp., haptera usually had several small branches (Figure 7 D). The medullary zone had cylindrical cells in a longitudinal direction, with the absence of trumpet filaments (Figure 7 

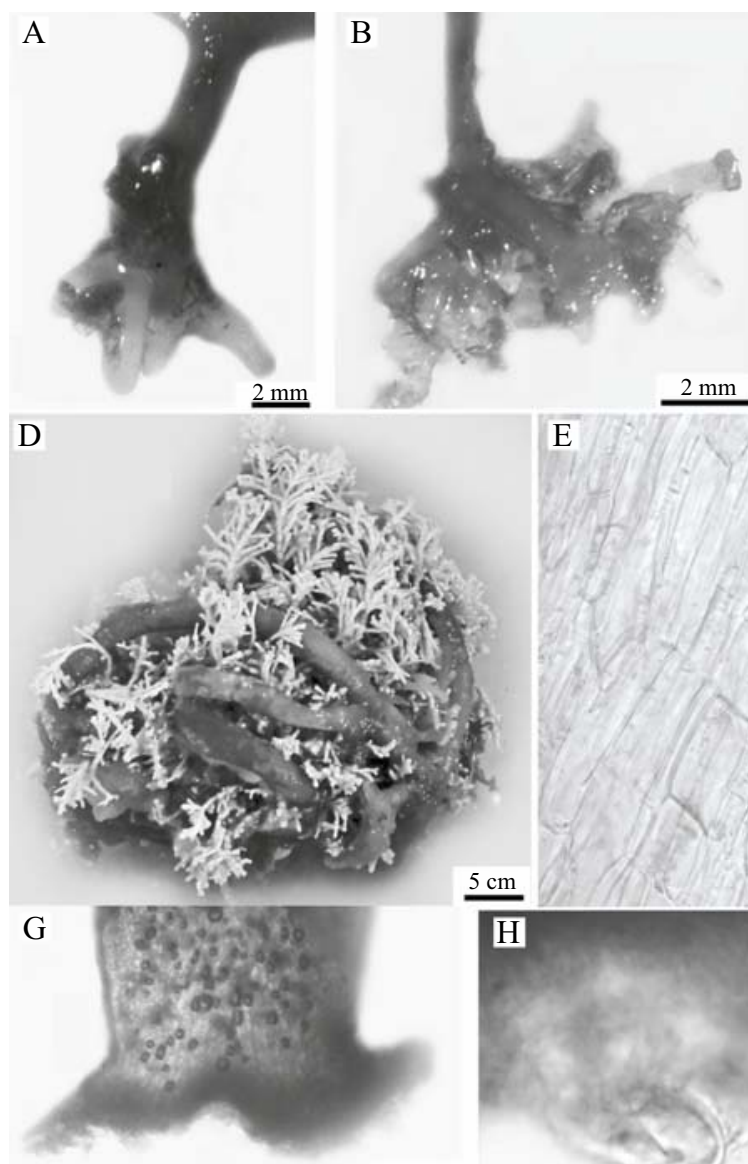

$20 \mu \mathrm{m}$
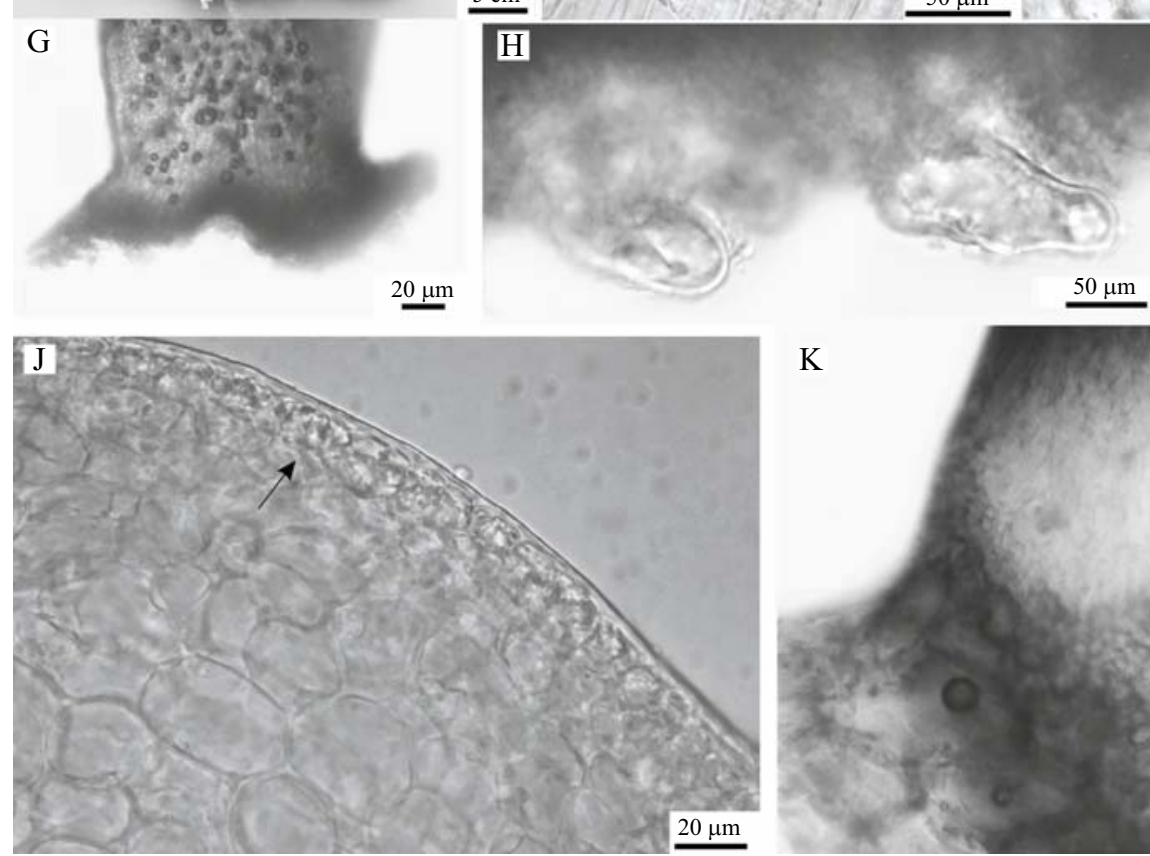

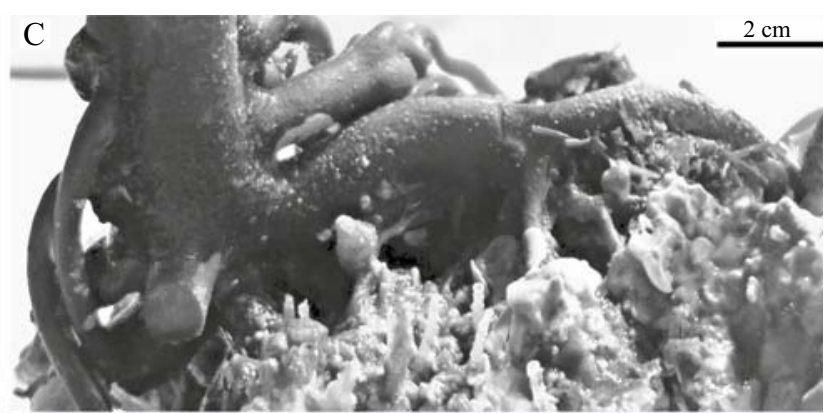

E
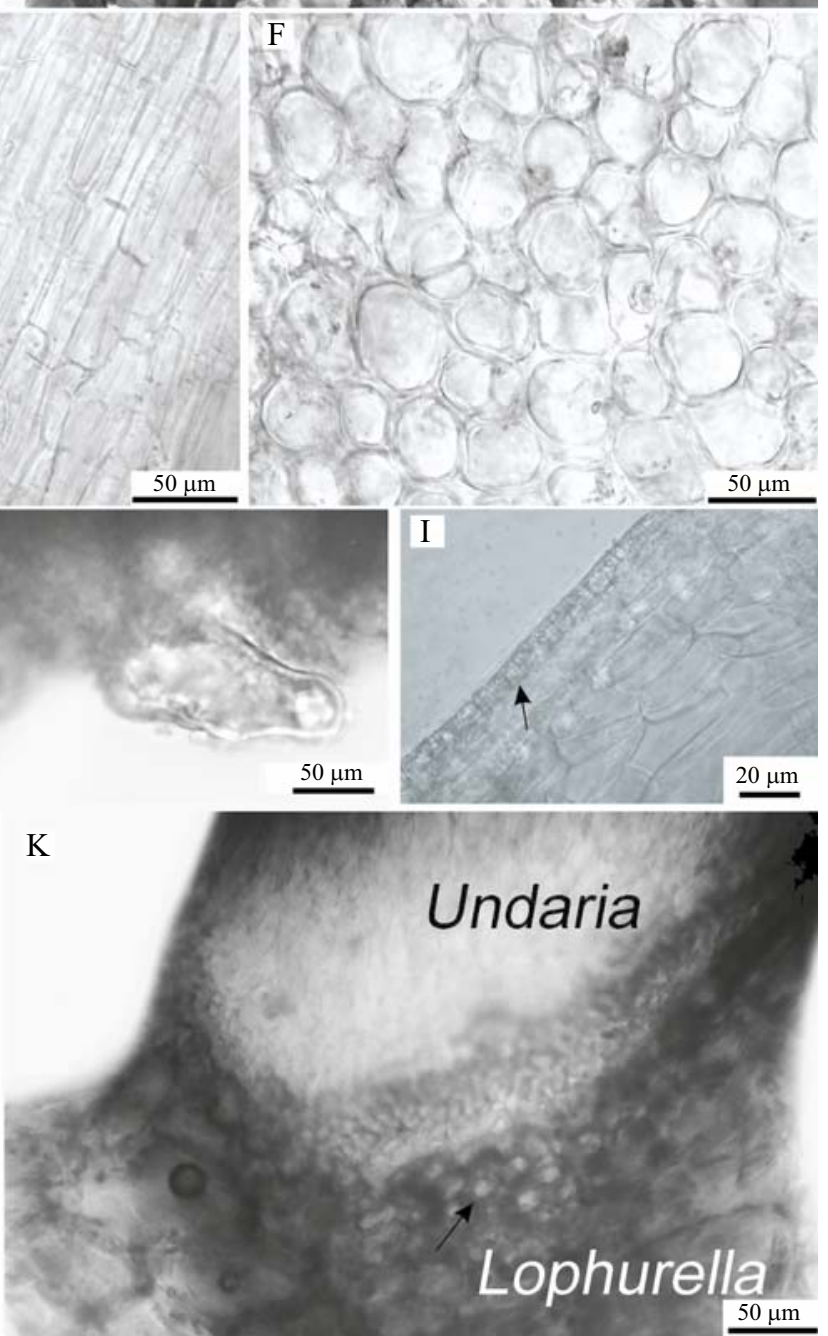

Figure 7. Holdfast. A) Young holdfast with two levels of dichotomy. B) Young holdfast with several levels of dichotomy. C) Adult holdfast with a few branches on encrusting corals. D) Adult holdfast with many branches on Corallina officinalis. E) Haptera longitudinal section, cylindrical cells of the medullary zone. F) Haptera cross section, cortical zone. G) Haptera apex detached from the hard substrate. H) Surface between haptera and rocky substrate. I) Haptera longitudinal section with undifferentiated cortical tissue and very thin epidermis. J) Haptera apex with undifferentiated cells. K) Haptera apex in contact with Lophurella. 
E), while the cortical zone of the holdfast was characterized by the presence of ovoid cells (Figure $7 \mathrm{~F}$ ). The contact points of the haptera with substrates were apical (Figure $7 \mathrm{G}$ ) or in the abaxial zone. On hard rock, haptera surface cells could be globose, hyaline and relatively undifferentiated at the contact points (Figure $7 \mathrm{H}$ ). In the cylindrical zones of the holdfast not in contact with the substrate, the haptera was made mostly of longitudinally elongated cells (Figure 7 I) covered by a stratum of flattened superficial cells; this stratum was absent from the zones in contact with the different substrates (Figure $7 \mathrm{~J}$ ).

When the thalli lived on thin, cylindrical algae, such as Lophurella hookeriana, haptera was surrounding their thalli, and somewhat a denser cellular tissue of smaller cells on both surfaces was formed (Figure $7 \mathrm{~K}$ ).

\section{DISCUSSION}

Morphology of Undaria pinnatifida has a genetic base and can also be affected by environmental factors (Saito 1972; Stuart et al. 1999; Park 2012). Sporophytes found in Undaria population from Caleta Cordova corresponded to those described as typical and distant forms, which matches the findings of Casas (2005) in Nuevo Gulf. Thalli of the distant form were found at greater depths, corresponding to the subtidal level, while thalli of the typical form were found at tidal pools.

Very evident transformations among embryonic stages were observed, in which the thallus consisted of a uniseriate frond adhered to the substrate only through the gametophyte, and adult thallus with different tissues showed marked specialization and complexity. Five main elements can be distinguished in the thallus of Undaria: frond, stipe, midrib, sporophyll and holdfast. These elements have been considered here to elucidate the deep transformations from the initial uniseriate fil- ament to the complex adult thallus of $U$. pinnatifi$d a$. Developmental differences observed between these portions of the thallus might be related to their distinct functionalities. Descriptions made in this work are comparable with those made by Casas (2005) for specimens from Nuevo Gulf.

Laminariales have a primary intercalary meristoderm that determines the general course of growth (Lee and Yoon 1998; Castric-Fey et al. 1999). In this study, meristoderm was observed between the frond and the stipe in U. pinnatifida. In the upper portion a row of small lateral cilia or pinnules was produced, from which the pinnae of the frond was developed. Adult frond morphology depends on the number of pinnules, which presented a very variable trait in samples from Caleta Cordova population. The final area of the frond is attained by the subsequent growth, which takes places through the meristoderm on the surface of the thallus.

Main functions of fronds are photosynthesis and nutrient absorption, both of which depend on the frond surface area. In the frond, the photosynthetic meristoderm gives rise to an inner, colorless layer of larger cells, which in turn produces a lax medullary zone. The loss of the frond apical tissue, observed even in young thalli, is effectively balanced by the pinnae and midrib elongation. This is characteristic of Laminares, in which new tissue formation and distal tissue loss occur at the same time (Larkum 1986; Skriptsova et al. 2004).

Yendo (1909) noted the presence of dark gland cells which were more abundant in very young thalli and young margins of pinnae. Our observations confirmed the greater abundance of gland cells at the growth zones of the fronds. The present study showed that hair-filled cryptostomata originated from gland cells. Pang and Lüning (2004) indicated that the quantity of hairs on the surface of fronds is critical for the quality of commercially harvested Undaria. These authors also suggested that the presence of hairs on the fronds was a response to a greater demand for nutrients originated from the expanded surface-volume 
ratio of the frond. Hairs could also play an important role in the prevention of herbivory (Schaffelke et al. 2005). In Argentina, Teso et al. (2009) registered scraped-off biofouling species on Undaria thalli. No signs of herbivory were observed in the present study.

Stipe and midrib of the frond contribute to the flexibility of the thallus and the orientation and movement of the frond. Stipe is longer at greater depths in order to locate fronds in areas with greater illumination (Cremades-Ugarte et al. 2006). These data agreed with observations in the coast of Caleta Cordova, where thalli corresponding to the distant form were found in the subtidal zone exposed to lower light intensity. Saito (1975) reported Undaria growing on sites with low to medium exposition to waves, while Russell et al. (2008) note its presence in higher dynamic conditions. In Caleta Cordova and nearby locations inside San Jorge gulf, $U$. pinnatifida populations are found in relatively protected sites, like small bays.

In the midrib and the stipe, the inner cortex is more developed with several colorless cell layers. The medullary zone is reduced to a thin plate, while the multi-layered compact cortex contributes to flexibility and strength, both necessary for withstanding water movements and for nutrient and gas absorption. Stipes maintains it structure until the end of the sporophyte life cycle.

Midrib would have a function similar to that of the sieve tubes of vascular plants due to the presence of structures such as screened plates, filaments and trumpet cells in their medullary zone. This structure is the most important site for the translocation of photoassimilates from the apical area to the basal area of the frond (Wu and Meng 1997).

The folded structure of the sporophyll generates an increase in the surface of the sori, favoring the reproductive capacity of this species, a characteristic of invasive species. The sporophyll structure is similar to the frond but thicker. Fertile sporangia are produced on its surface in an almost continuous layer. Schaffelke et al. (2005) reported that functional zoospores are only liberated from the most mature zones of the sporophyll, far from the meristem. This assertion is true only for younger fertile thalli, since sporophyll development continues until it occupies the entire length of the stipe.

The capacity to adhere to the available substrata is essential for survival in each developmental stage of Undaria, and is a characteristic of the opportunistic seaweed able to rapidly colonize new or disturbed substrata and artificial floating structures (Hay 1990; Valentine and Johnson 2003, 2004). Undaria can also develop as an epibion of marine invertebrates (CremadesUgarte 2006). Embryonic frond is at first adhered through the gametophyte and is later attached by a few, thin, very characteristic lateral filaments. In the juvenile stage, a holdfast primordium is formed, whose haptera later divide dichotomically. The holdfast has a less complex structure than the frond or the stipe, with a single layer of epidermis and a cortex. However, a greater diversity of tissues can be found at the contact points of the haptera with different kinds of substrate.

Morphological structures observed in this study are typical of this species and provide information on the characteristics of the thallus at each stage of development, which will be useful for subsequent analyses.

\section{ACKNOWLEDGEMENTS}

We thank Lic. Juan Manuel Zaixso and Dr. Mauro Marcinkevicius for their assistance in the field, and Dr. Patricia Leonardi for her observations. This study is part of the $\mathrm{PhD}$ thesis of María Victoria Alvarez at the Universidad Nacional de la Patagonia San Juan Bosco, supported by a student grant from the Consejo Nacional de Investigaciones Científicas y Técnicas (CONICET). 


\section{REFERENCES}

Aguilar-Rosas R, Aguilar-Rosas LE, ÁvilaSerrano G, Marcos-Ramírez R. 2004. First record of Undaria pinnatifida (Harvey) Suringar (Laminariales, Phaeophyta) on the Pacific coast of Mexico. Bot Mar. 47: 255258.

Boudouresque CF, Gerbal M, KnoepfFler Peguy M. 1985. L'algue japonaise Undaria pinnatifida (Phaeophyceae, Laminariales) en Mediterranee. Phycologia. 24: 364- 366.

CAmpBell SJ, BurRidge TR. 1998. Occurrence of Undaria pinnatifida (Phaeophyta, Laminariales) to Port Phillip Bay, Victoria, Australia. Mar Freshw Res. 49: 379-381.

CASAS GN. 2005. Biología y ecología de Undaria pinnatifida (Phaeophyceae, Laminariales) en Golfo Nuevo (Chubut, Argentina) [PhD thesis]. Bahía Blanca: Universidad Nacional del Sur, $246 \mathrm{p}$.

CASAs GN, PIRIz ML. 1996. Surveys of Undaria pinnatifida (Laminariales, Phaeophyta) in Golfo Nuevo, Argentina. Hydrobiología. 326/327: 213-215. doi:10.1007/BF00047809

Casas GN, Piriz ML, Parodi ER. 2008. Population features of the invasive kelp Undaria pinnatifida (Phaeophyceae: Laminariales) in Nuevo Gulf (Patagonia, Argentina). J Mar Biol Assoc UK. 88 (1): 21-28.

Castric-Fey A, Beaupoil C, Bouchain J, Pradier E, L'Hardy Halos MT. 1999. The Introduced Alga Undaria pinnatifida (Laminariales, Alariaceae) in the Rocky Shore Ecosystem of the St Malo Area: growth rate and longevity of the sporophyte. Bot Mar. 42: 83-96. doi:10.1515/BOT.1999.011

Castric-Fey A, Girard A, L'Hardy-Halos MTH. 1993. The distribution of Undaria pinnatifida (Harvey) Suringar (Phaeophyceae, Laminariales) on the coast of St. Malo (Brittany, France). Bot Mar. 36: 351-358.
Cecere R, Petrocelli A, Saracino OD. 2000. Undaria pinnatifida (Fucophyceae, Laminariales) spread un the central Mediterranean: its ocurrence in the Mar Piccolo of Taranto (Ionian Sea, southern Italy). Cryptogam Algol. 21: 305-309.

Cremades-Ugarte J, Freire-Gago Ó, PeteiroGARCía C. 2006. Biología, distribución e integración del alga alóctona Undaria pinnatifida (Laminariales, Phaeophyta) en las comunidades bentónicas de las costas de Galicia (NW de la Península Ibérica). An Jard Bot Madr. 63 (2): 169-187. doi:10.3989/ajbm.2006.v63.i2.6 Curiel D, Guidetti P, Bellemo G, Scattolin M, MARzOCCHI M. 2002. The introduced alga Undaria pinnatifida (Laminariales, Alariaceae) in the lagoon of Venice. Hydrobiologia. 477: 209-219. doi:10.1023/A:1021094008569

Curiel D, Rismondo A, Marzocchi M, Solazzi A. 1994. Distibuzione di Undaria pinnatifida (Laminariales, Phaeophyta) nella Laguna di Venezia. Lavori Soc Ven Sc Nat. 19: 129-136.

Dellatorre FG, Amoroso R, Saravia J, OrenSANZ JM. 2014. Expansion and potential range of the invasive kelp Undaria pinnatifida in the Southwest Atlantic. Aquat Invasions. 9 (4): 467-478.

DIETRICH M, LONHART SI. 2010. Undaria pinnatifida: testing different methods of removal and the re-growth potential of an invasive kelp. A report submitted to the Monterey Bay National Marine Sanctuary Sanctuary Integrated Monitoring Network (SIMoN) September 18. $11 \mathrm{p}$.

FletCher RL, MANFREDI C.1995. The occurrence of Undaria pinnatifida (Phaeophyceae, Laminariales) on the south coast of England. Bot Mar. 38: 1-4.

Floc'h JY, Pajot R, Wallentinus I. 1991. The Japanese brown alga Undaria pinnatifida on the coast of France and its possible establishment in European waters. J Cons int Explor Mer. 47: 379-390.

García Tasende M, Peteiro C. 2015. Explota- 
ción de las macroalgas marinas: Galicia como caso de estudio hacia una gestión sostenible de los recursos. Ambienta. 111: 116-132.

GIL DG, ZAIXso HE. 2008. Feeding ecology of the sub-Antarctic sea star Anasterias minuta within tide pools in Patagonia, Argentina. Rev Biol Trop. 56: 311-328.

Guiry MD, Guiry GM. 2014. AlgaeBase. Worldwide electronic publication. National University of Ireland, Galway. [accessed 2014 April 1]. http://www.algaebase.org.

HAY CH. 1990. The dispersal of sporophytes of Undaria pinnatifida by coastal shipping in New Zealand, and implications for further dispersal of Undaria in France. Br Phycol J. 25: 301-313.

HaY CH, LuCKens PA. 1987. The Asian kelp Undaria pinnatifida (Phaeophyta; Laminariales) found in a New Zealand harbour. N Z J Bot. 25: 329-332.

LARKUM AWD. 1986. A study of growth and primary production in Eklonia radiata (C. Ag.) J. Agardh (Laminariales) at a sheltered site in a Port Jackson, New South Wales. J Exp Mar Biol Ecol. 96: 177-190.

LEE YP, Yoon JT. 1998. Taxonomy and Morphology of Undaria (Alariaceae, Phaeophyta) in Korea. Algae. 13 (4): 427-446.

Martin JP, Cuevas JM. 2006. First record of Undaria pinnatifida (Laminariales, Phaeophyta) in Southern Patagonia, Argentina. Biol Invasions. 8: 1399-1402. doi:10.1007/s10530006-0004-7

Meretta PE, Matula CV, Casas G. 2012. Occurrence of the alien kelp Undaria pinnatifida (Laminariales, Phaeophyceae) in Mar del Plata, Argentina. Bioinvasions Rec. 1 (1): 5963. doi:10.3391/bir.2012.1.1.13

Minchin D, Num J. 2014. The invasive brown alga Undaria pinnatifida (Harvey) Suringar, 1873 (Laminariales: Alariaceae), spreads northwards in Europe. Bioinvasions Rec. 3 (2): 57-63. doi:10.3391/bir.2014.3.2.01

Minchin D, NunN J, Murphy J, Edwards J,
DownIE A. 2017. Monitoring temporal changes in the early phase of an invasion: Undaria pinnatifida (Harvey) Suringar using the abundance and distribution range method. Manag Biol Invasion. 8 (1): 53-6. doi:10.3391/ mbi.2017.8.1.05

OKAMURA K. 1915. Undaria and its species. Bot Mag Tokyo. 29: 269-281.

PANG S, LÜNING K. 2004. Photoperiodic long-day control of sporophyll and hair formation in the brown alga Undaria pinnatifida. J Appl Phycol. 16: 83-92. doi:10.1023/B: JAPH.00000 44773.52572.8b

PANG S, Wu CH. 1996. Study on gametophyte vegetative growth of Undaria pinnatifida and its applications. Chin J Oceanol Limnol. 14 (3): 205-210.

Park KJ, Kim BY, Park SK, LeE JH, Kim YS, Chol HG, NAm KW. 2012. Morphological and biochemical differences in three Undaria pinnatifida populations in Korea. Algae. 27 (3): 189-196. doi:10.4490/algae.2012.27.3.189

Pereyra PJ, Arias M, González R, Narvarte M. 2014. Moving forward: the Japanese kelp Undaria pinnatifida (Harvey) Suringar, 1873 expands in northern Patagonia, Argentina. Bioinvasions Rec. 3: 65-70. doi:10.3391/bir. 2014.3.2.02

Pereyra PJ, Narvarte M, Tatián M, GonzÁlez R. 2015. The simultaneous introduction of the tunicate Styela clava (Herdman, 1881) and the macroalga Undaria pinnatifida (Harvey) Suringar, 1873, in northern Patagonia. Bioinvasions Rec. 4: 179-184. doi:10.3391/bir. 2015.4.3.04

Perez R, KaAs R, Barbaroux O. 1984. Culture experimentale de l'algue Undaria pinnatifida sur les cotes de France. Science et Peche. 343: 5-15.

Perez R, Lee JY, Juge C. 1981. Observations sur la biologie de l'algue Undaria pinnatifida (Harvey) Suringar introduite accidentellement dans l'etang de Thau. Science et Peche. 315: $1-12$. 
Perez-Cirera JL, Salinas JM, Cremades J, Bárbara I, Granja A, Veiga AJ, Fuertes C. 1997. Cultivo de Undaria pinnatifida (Laminariales, Phaeophyta) en Galicia. Nova Acta Cient Compostel Biol. 7: 3-28.

Peteiro C. 2001. Cultivo experimental con fines industriales de Undaria pinnatifida (Laminariales, Phaeophyta) en la Ría de Ares y Betanzos (A Coruña). Unpublished Degree Thesis. Universidad da Coruña, España.

Peteiro C. 2008. A new record of the introduced seaweed Undaria pinnatifida (Laminariales, Phaeophyceae) from the Cantabrian Sea (northern Spain) with comments on its establishment. Aquat Invasions. 3: 413-415. doi:10. 3391/ai.2008.3.4.7

PIRIZ ML, CASAS G. 1994. Occurrence of Undaria pinnatifida in Golfo Nuevo, Argentina. Applied Phycology Forum. 10 (3): 4.

PIRIZ ML, CASAS G. 2001. Introduction of species and its impact on biodiversity. The Undaria pinnatifida case (Phaeophyta, Laminariales). In: Alveal K, Antezana T, editors. Sustainability of biodiversity. Concepción: Universidad de Concepción. p. 679-692.

Rismondo A, Volpe S, Curiel D, Solazzi A. 1993. Segnalazione di Undaria pinnatifida (Harvey) Suringar a Chioggia (Laguna Veneta). Lavori Soc Ven Sc Nat. 18: 328-330.

Russell LK, Hepburn CD, Hurd CL, Stuart MD. 2008. The expanding range of Undaria pinnatifida in southern New Zealand: distribution, dispersal mechanisms and the invasion of wave-exposed environments. Biol Invasions. 10: 103-115. doi:10.1007/s10530-007-9113-1

Salinas JM, Llera EM, Fuertes C. 1996. Nota sobre la presencia de Undaria pinnatifida (Harvey) Suringar (Laminariales, Phaeophyta) en Asturias (mar Cantábrico). Bol Inst Esp Oceanogr. 12: 77-79.

SANDERSON J. 1990. A preliminary survey of the distribution of the introduced macroalga Undaria pinnatifida (Harvey) Suringar on the east coast of Tasmania, Australia. Bot Mar. 33:
153-157.

SAITO Y. 1972. On the effects of environmental factors on morphological characteristics of Undaria pinnatifida and the breeding of hybrids in the genus Undaria. In: Аввот IA, Kurogi M, editors. Contributions to the systematics of benthic marine algae of the North Pacific. JSP Kobe. p. 117-134.

SAito Y. 1975. Undaria. In: ToKida J, Hirose H, editors. Advance of phycology in Japan. The Hague: Dr. W. Junk b. v. Publishers. p. 304320.

Santiago-CaAmaño J, Duran-Neira C, AcuñaCastroviejo R. 1990. Aparición de Undaria pinnatifida en la costas de Galicia (España). Un nuevo caso en la problemática de introducción de especies foráneas. Informes Técnicos, Centro de Investigaciones Submarinas (CIS). $43 \mathrm{p}$.

Schaffelke B, Campbell ML, Hewitt CHL. 2005. Reproductive phenology of the introduced kelp Undaria pinnatifida (Phaeophyceae, Laminariales) in Tasmania, Australia. Phycologia. 44: 84-94.

SHIBNEVA SY, SKRIPTSOVA AV. 2012. Morphological variability of Undaria pinnatifida (Phaeophyceae: Laminariales) in Peter the Great Bay (Sea of Japan). Russ J Mar Biol. 38: 381-39.

Silva PS, WoOdFIEld RA, COHEN AN, Harris LH. 2002. First report of the Asian kelp Undaria pinnatifida in the northeastern Pacific Ocean. Biol Invasions. 4: 333-338.

SKRIPTSOVA AV, KHOMENKO VA, ISAKOV VV. 2004. Seasonal changes in growth rate, morphology, and alginate content in Undaria pinnatifida at the northern limit in the Sea of Japan (Russia). J Appl Phycol. 16: 17-21. doi:10.1023/B:JAPH.0000019049.74140.61

STAPLETON JC. 1988. Occurrence of Undaria pinnatifida (Harvey) Suringar in New Zealand. Jpn J Phycol. 36: 178-179

Stuart MD, Hurd CL, Brown MT. 1999. Effects of seasonal growth rate on morphological variation of Undaria pinnatifida (Alari- 
aceae, Phaeophyceae). Hydrobiologia. 398: 191-199. doi:10.1023/A:1017012301314

Teso SV, Bigatti G, Casas GN, Piriz ML, PenCHASZADEH PE. 2009. Do native grazers from Patagonia, Argentina consume the invasive kelp Undaria pinnatifida? Rev Mus Argentino Cienc Nat ns. 11 (1): 7-14.

Thornber CS, Kinlan BP, Graham MH, StaCHOWICZ JJ. 2004. Population ecology of the invasive kelp Undaria pinnatifida in California: environmental and biological controls on demography. Mar Ecol Prog Ser. 268: 69-80.

VALENTINE J P, JOHNSON CR. 2003. Establishment of the introduced kelp Undaria pinnatifida in Tasmania depends on disturbance to native algal assemblages. J Exp Mar Biol Ecol. 29: 63-90.

VALENTINE JP, JOHNSON CR. 2004. Establishment of the introduced kelp Undaria pinnatifida following dieback of the native macroalga Phyllospora comosa in Tasmania, Australia. Mar Freshw Res. 55 (3): 223-230.

Uwai, Sy, Nelson W, NeIll K, Wang WD, Aguilar-Rosas LE, Boo SM, Kitayama T, KawA H. 2006. Genetic diversity in Undaria pinnatifida (Laminariales, Phaeophyceae) deduced from mitochondria genes origins and succession of introduced populations. Phycologia. 45: 687-695.

Williams SL, Smith J.E. 2007. A global review of the distribution, taxonomy and impact of introduced seaweeds. Annu Rev Ecol Evol Syst. 38: 327-359. doi:10.3391/bir.2012.1.1.13

Wu CY, Meng JX.1997. Translocation of assimilates in Undaria and its cultivation in China. Hydrobiologia. 352: 287-293.

YeNDO K. 1909. On the mucilage glands of Undaria. Ann Bot. 23 (92): 613-621.

Yendo K. 1911. The development of Costaria, Undaria and Laminaria. Ann Bot. 25: 691715.

Zaixso HE, Stoyanoff P, Gil DG. 2009. Detrimental effects of the isopod, Edotia doellojuradoi, on gill morphology and host condition of the mussel, Mytilus edulis platensis. Mar Biol. 156 (11): 2369-2378.

Received: 26 March 2020

Accepted: 26 May 2020 